\title{
Mauremys rivulata (Valenciennes in Bory de Saint-Vincent 1833) - Western Caspian Turtle, Balkan Terrapin
}

\author{
Georgia Mantziou ${ }^{1,3}$ and Lina Rifai ${ }^{2}$
}

\author{
${ }^{1}$ Natural History Museum of Crete, University of Crete, Knossou Ave., 71409 Irakleio, Crete, Greece; \\ ${ }^{2}$ Department of Biology, School of Sciences, Indiana University Kokomo, \\ 2300 S. Washington St., P.O. Box 9003, Kokomo, Indiana 46904 USA [lrifai@iuk.edu]; \\ 3Present Address: 9 Edington Grove, Wellington 6037, New Zealand [georgiam74@yahoo.com]
}

Summary. - Mauremys rivulata (Family Geoemydidae) is a medium-sized freshwater turtle (carapace length to ca. $240 \mathrm{~mm}$ in females, ca. $185 \mathrm{~mm}$ in males) inhabiting various natural and manmade habitats, including rivers, seasonal ponds, lakes, brackish coastal lagoons, irrigation canals, and reservoirs. It is adapted to a warm Mediterranean climate and is common and widespread and can be found in high densities; it is not considered particularly threatened. Habitat destruction and degradation has lead to some population declines, however, and in some cases, extirpation of marginal and island populations. Preservation of its habitats and control of the introduced species Trachemys scripta are recommended for the conservation of the species.

Distribution. - Albania, Bosnia and Herzegovina, Bulgaria, Croatia, Cyprus, Greece, Israel, Jordan, Lebanon, Macedonia, Montenegro, Palestine, Serbia, Syria, Turkey. Occurs in the Balkan region of southeastern Europe and the eastern Mediterranean, including southern coastal Turkey and the western Middle East.

Synonymy.-Emys rivulata Valenciennes in Bory de Saint-Vincent 1833, Clemmys caspica rivulata, Mauremys caspica rivulata, Mauremys rivulata, Mauremys rivulata rivulata, Emmenia rivulata, Emys tristrami Gray 1869, Mauremys rivulata tristrami, Emys caspica arabica Gray 1870, Emys pannonica Gray 1870, Clemmys caspica orientalis Bedriaga 1881, Clemmys caspica obsoleta Schreiber 1912, Clemmys caspica cretica Mertens 1946, Mauremys caspica cretica, Mauremys rivulata cretica.

SubsPECIES. - None.

Status. - IUCN 2014 Red List: Not Evaluated (NE); TFTSG Draft Red List: Least Concern (LC, assessed 2011); CITES: Not Listed; EU Council: Annex II, IV; Bern Convention: Appendix II.

Taxonomy. - Mauremys rivulata Valenciennes in Bory de Saint-Vincent 1833 was first described from Morea, in Greece, under the name Emys rivulata. Günther (1864), and also Tristram (1884), in his survey of western
Palestine, classified the species encountered there as Emys caspica. Böttger (1880) classified this widespread species ranging from Dalmatia through the whole of Southeastern Europe, Transcaucasia, Persia, the edges of the Euphrates,

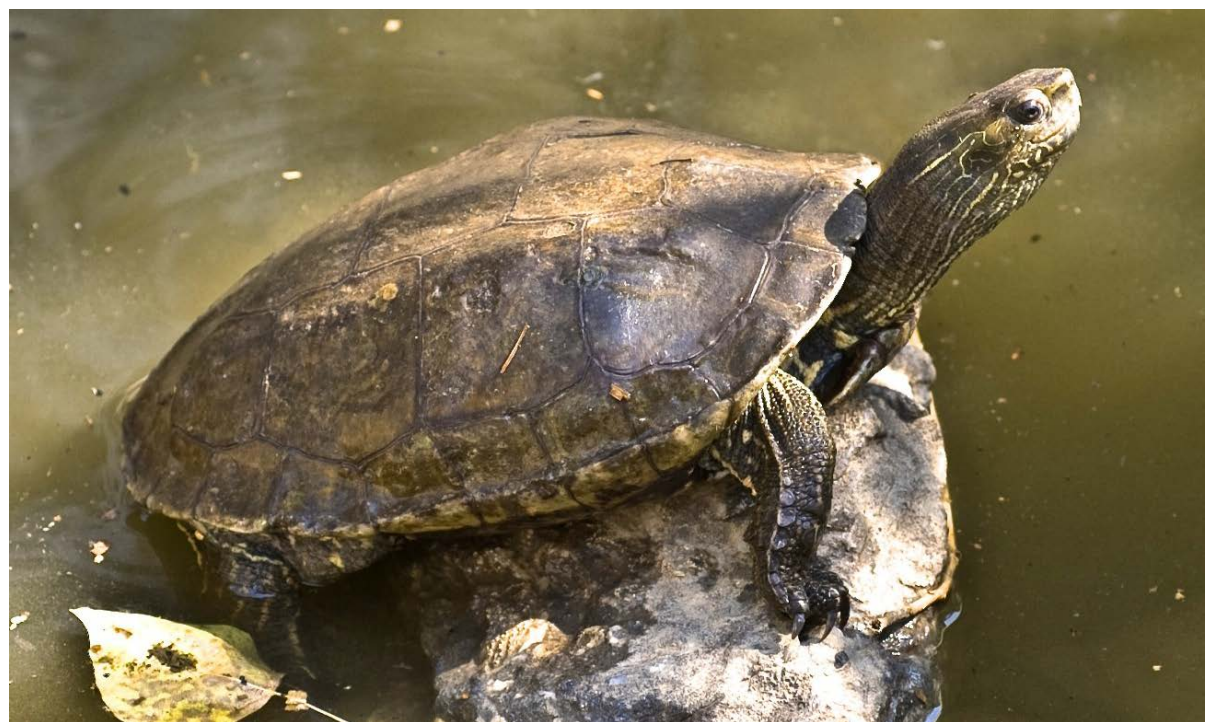

Figure 1. Adult Mauremys rivulata from Crete, Greece. Photo by Apostolis Trichas, Natural History Museum of Crete (NHMC). 

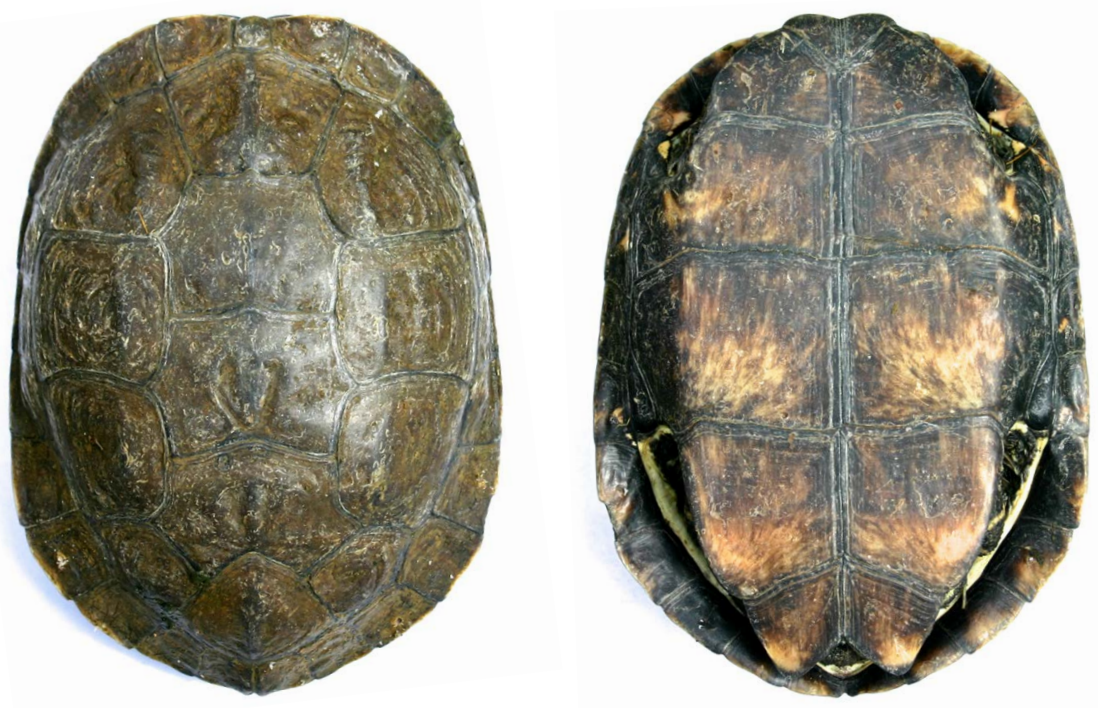

Figure 2. Adult female Mauremys rivulata from Almyros River, Irakleio, Crete, Greece. Photos by Georgia Mantziou.

Asia Minor, Syria and Palestine, as Clemmys caspica, but he differentiated the western populations from the eastern ones and considered them to be the subspecies Clemmys caspica rivulata. Siebenrock (1913) revised the status of the three Mediterranean taxa of the genus Clemmys $(C$. caspica caspica, C. caspica rivulata, and C. leprosa) and emphasized the differences between caspica and rivulata. He noted one of the main distinguishing characteristics of these two subspecies was the coloration of the bridge, which was yellow in caspica, but black or brown in rivulata.

In subsequent literature the taxon was referred to as either C. caspica or C.c. rivulata (Wettstein 1928, Werner 1939, Mertens 1946, Wettstein 1951, Anderson 1963, Eiselt and Spitzenberger 1967,Zinner 1967). Mertens (1946) in his study of the Mediterranean turtles described the subspecies C. c. cretica from Crete, but Mertens and Wermuth (1960) later synonymized this taxon with rivulata.

McDowell (1964) revised the taxonomy of Clemmys, based mainly on skull characteristics, and divided the

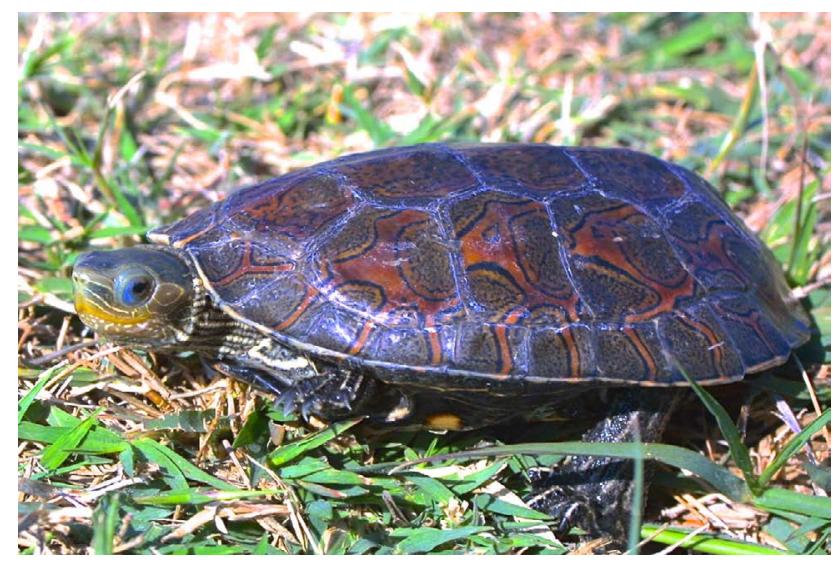

Figure 3. Male Mauremys rivulata from Birket Arayes, Jordan. Photo by Lina Rifai.
Testudinid subfamily of the Emydinae into two subfamilies: Emydinae and Batagurinae. He considered the Emydinae to include almost entirely New World turtles with one single Old World genus, Emys, while the Batagurinae consisted mostly of Old World turtles and one New World genus, Rhinoclemmys. He placed the Old World species that had previously been included in the genus Clemmys in the genus Mauremys.

Eiselt and Spitzenberger (1967) clarifed the systematics, morphology and distribution of Clemmys caspica and its two subspecies, caspica and rivulata, in Turkey. They gave clear ranges for each subspecies, with C.c. caspica occurring in the east and southeast of the country, with C.c. rivulata in the west. They corrected several misidentifications made earlier in the literature and emphasized that there were no sympatric occurrences of those two subspecies. They noted that the nominotypic form has vertical, parallel and intensely yellow cross-stripes on the posterior sides of the legs, while these markings were absent in rivulata.

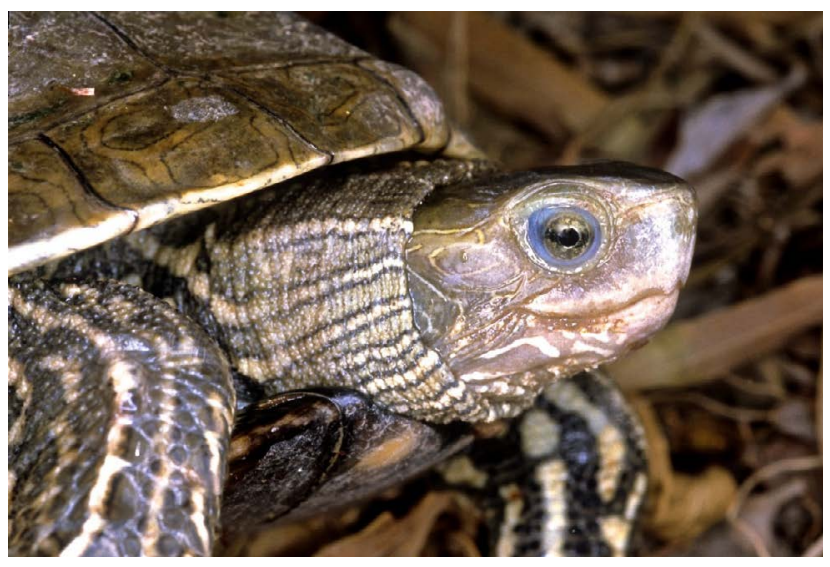

Figure 4. Head view of Mauremys rivulata from Crete, Greece. Photo by Apostolis Trichas, NHMC. 


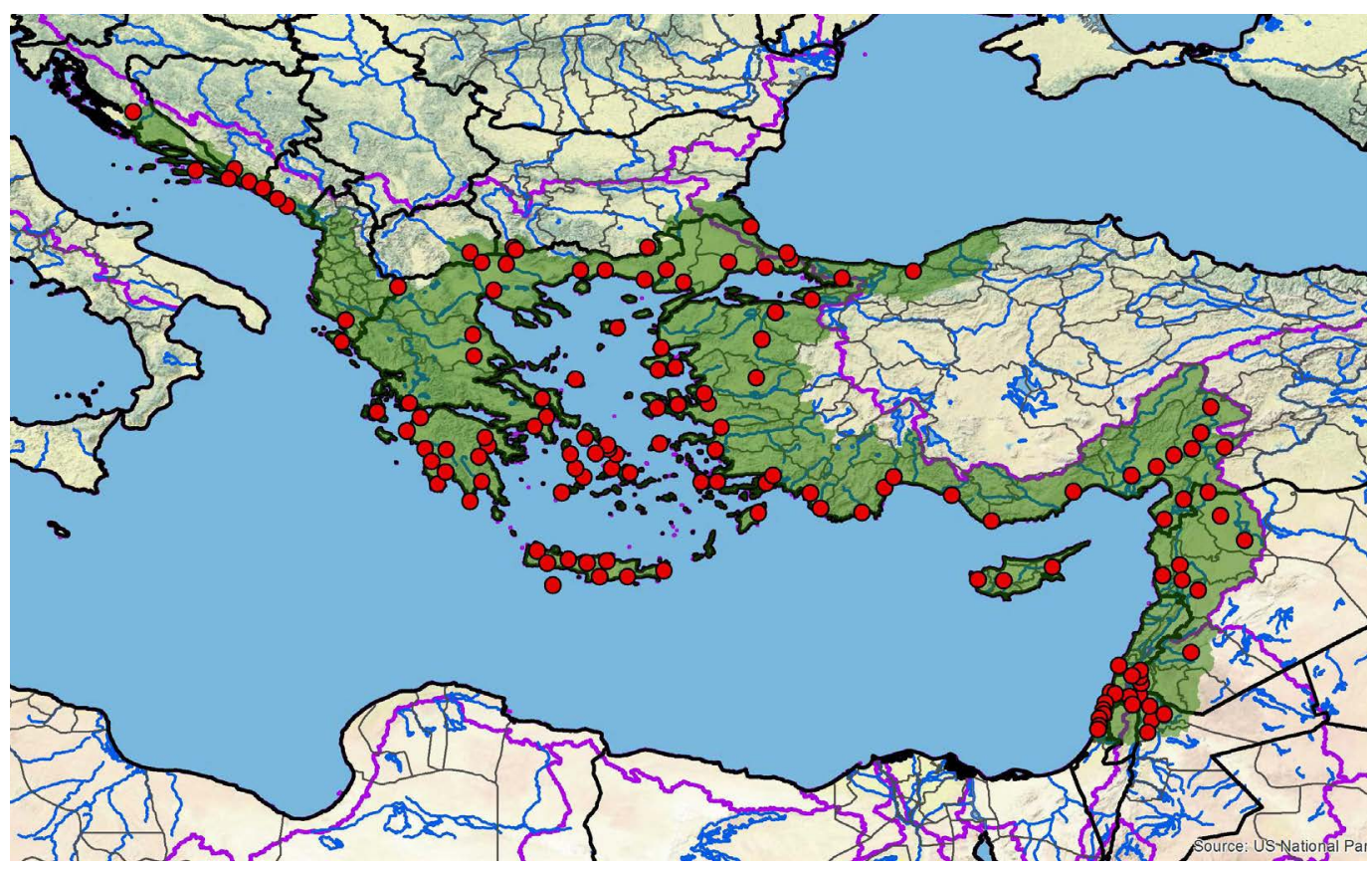

Figure 5. Distribution of Mauremys rivulata in the Balkans of southeastern Europe and the eastern Mediterranean. Purple lines = boundaries delimiting major watersheds (level 3 hydrologic unit compartments - HUCs); red dots = museum and literature occurrence records of native populations based on Iverson (1992) plus more recent and authors' data; green shading = projected native distribution based on GIS-defined HUCs constructed around verified localities and then adding HUCs that connect known point localities in the same watershed or physiographic region, and similar habitats and elevations as verified HUCs (Buhlmann et al. 2009; TTWG 2014), and adjusted based on authors' subsequent data.

Busack and Ernst (1980) studied the taxonomy of the three subspecies of Mauremys caspica (caspica, leprosa, and rivulata). Based on morphological, distributional, and biochemical data, they concluded that M. c. leprosa should be considered a separate species, M. leprosa.

In their taxonomic study of the genus Mauremys, Fritz and Wischuf (1997) recognized that there is a clear geographical partition between M. caspica caspica and $M$. caspica rivulata and only two local populations near the Turkish-Syrian border were found to have hybrids of both

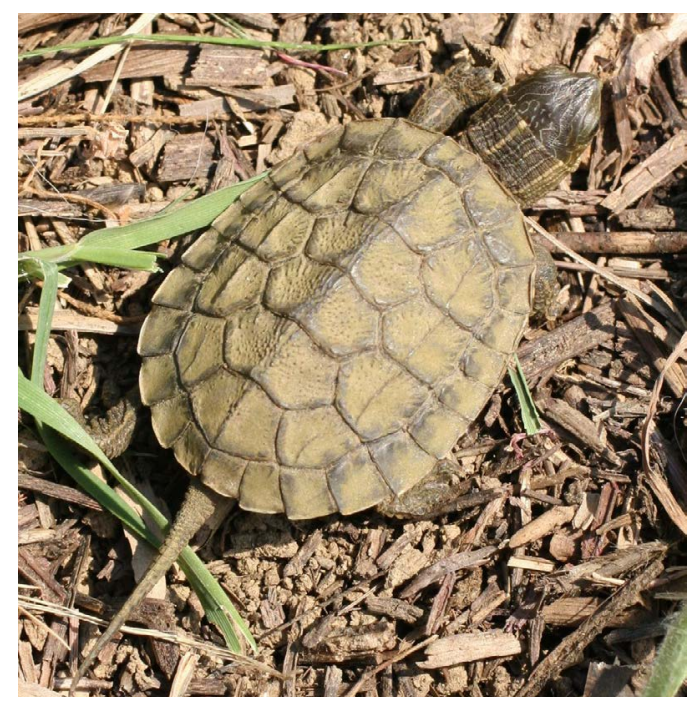

Figure 6. Hatchling Mauremys rivulata from Crete, Greece. Photo by Anders G.J. Rhodin. species. These hybrids were considered to be accidental exceptions (Fritz and Wischuf 1997) and the populations are now extirpated (Fritz et al. 2008). Morphometric features could not separate the two subspecies, but they suggested species status on the basis of the geographic separation and the color pattern of the carapace and plastron.

The elevation of $M$. rivulata to species level was later confirmed by molecular data, using both mitochondrial DNA and nuclear markers (Mantziou et al. 2004; Barth et al, 2004; Mantziou 2006; Fritz et al. 2008). Another small hybrid population was recently discovered in northwestern Turkey, but hybridization between M.rivulata and M.caspica is considered extremely rare and, apart from the three hybrid populations (Fritz and Wischuf 1997; Fritzet al.2008), there
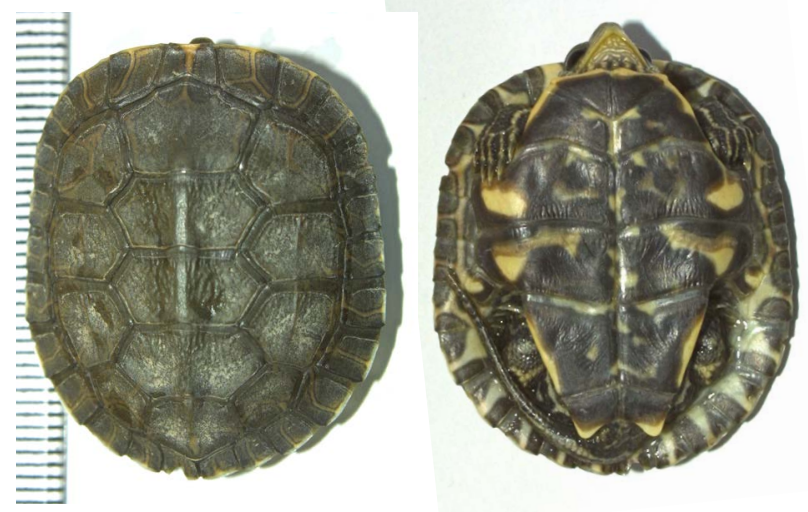

Figure 7. Hatchling Mauremys rivulata from BirketArayes, Jordan. Photos by Lina Rifai. 


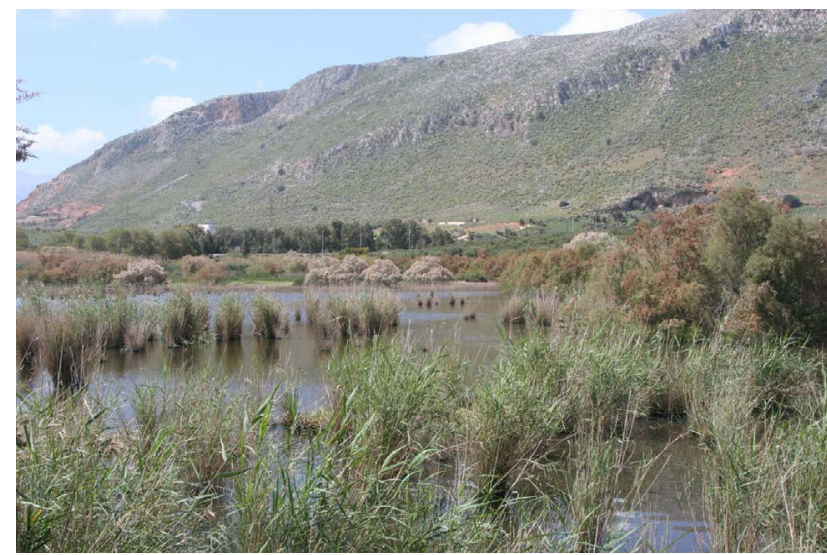

Figure 8. Shallow marshy natural Mauremys rivulata habitat on Crete, Greece, with a very dense turtle population. Photo by Anders G.J. Rhodin.

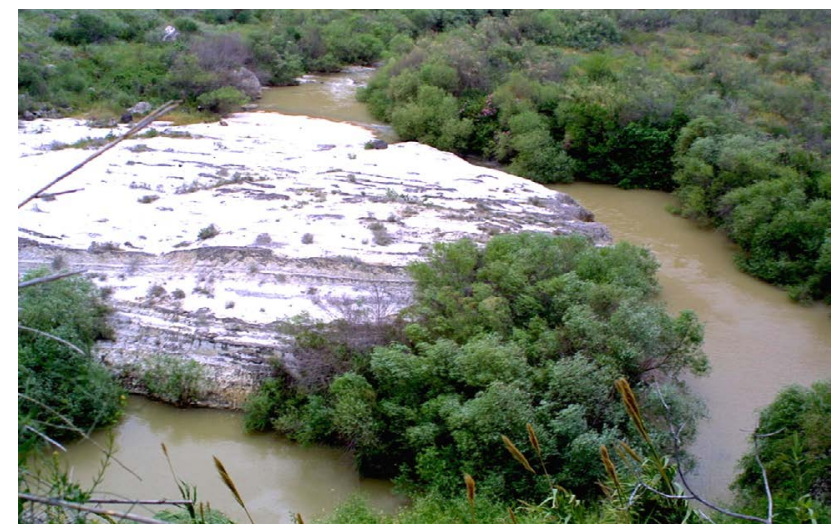

Figure 10. Mauremys rivulata habitat in Jordan: Yarmuk River. Photo by Lina Rifai.

is no evidence of gene flow between the species (Fritz et al. 2008).

Description. - Shell size in M. rivulata reaches a straight carapace length (CL) of up to $244 \mathrm{~mm}$ in females, and up to $187 \mathrm{~mm}$ in the slightly smaller males (Rifai and Amr 2004; Mantziou 2006). Males usually have a longer post-anal tail length, and the base of the tail is wider than that of females. Males have a generally flatter appearance than females and their plastron is slightly concave (Wischuf and Busack 2001; Rifai and Amr 2004).

The dorso-ventrally flattened and slightly bulged carapace of M.rivulata usually consists of 11 marginals and one supracaudal on each side. One nuchal, four costal and five vertebral scutes are present on the carapace. A strong median keel passes through the vertebrals. This keel is often more pronounced in younger individuals, where a less developed keel also passes through the costals on each side. Those two keels are often absent or very weakly developed in adults. The anals are notched in both sexes. The forelimbs have five claws, while the hindlimbs have only four (Wischuf and Busack 2001).

The carapace of adults is usually uniformly brown, or olive green to green, with faint or no pattern. Younger

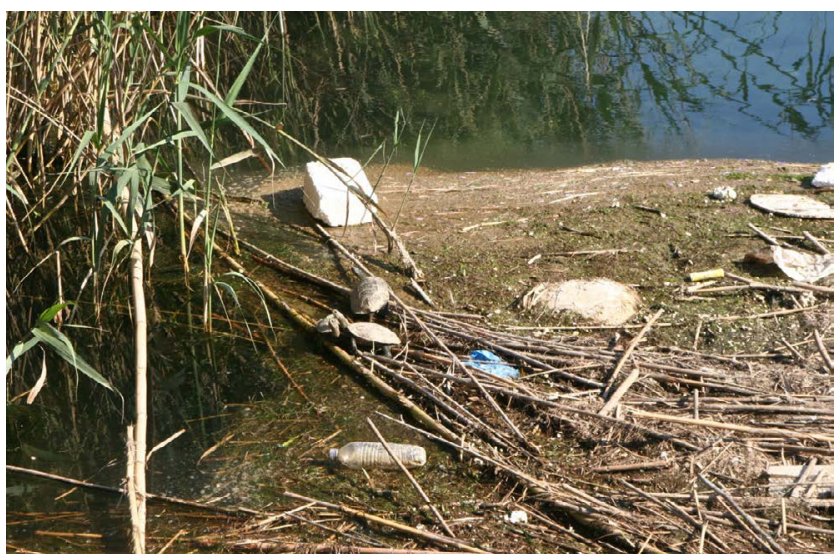

Figure 9. Polluted artificial irrigation canal on Crete, Greece, with several Mauremys rivulata basking. Photo by Anders G.J. Rhodin.

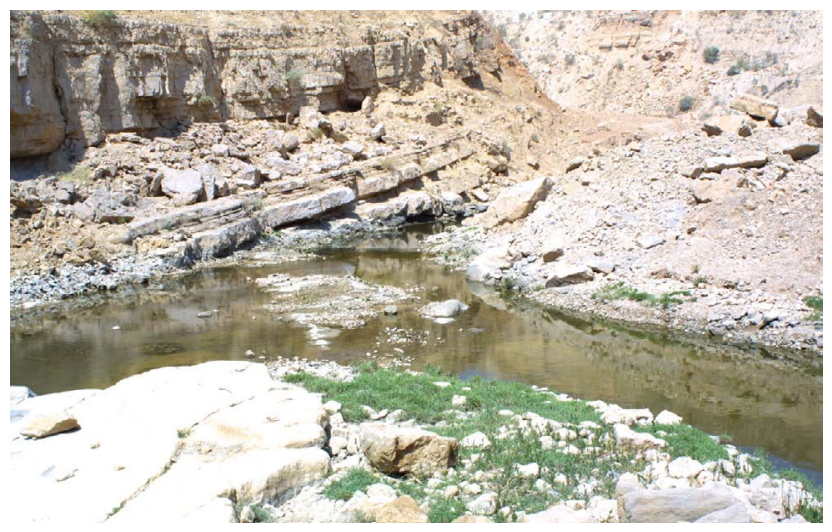

Figure 11. Mauremys rivulata habitat in Jordan: Zarqa River before the King Talal Dam (south of Jerash). Photo by Lina Rifai.

specimens exhibit obvious, reddish-brown or sometimes yellowish light and irregular reticulate patterns, that extend beyond the scutes to the adjacent scutes on a green to dark background. The plastron of younger animals is generally dark to black medially, while on the outer edges of the scutes yellowish shapes can be present. Adults rarely have light shapes; however, with age the plastron lightens up and appears more yellowish overall. The bridge is generally uniformly dark to black, sometimes light yellow spots can be seen on its margins (Wischuf and Busack 2001). The snout of $M$. rivulata has thin stripes that can sometimes be completely absent or often only two are present.

Hatchlings measure 30-40 mm CL; their carapace has a strong medial keel and they generally have yellowish to orange reticulate patterns on the carapace and pronounced color patterns on the plastron (Wischuf and Busack 2001).

Genetic markers and the fossil record suggest a western Asian origin for the species (Mantziou 2006; Fritz et al. 2008). The phylogeographic pattern of $M$. rivulata is shaped by dispersal events, which took place during the Pliocene, Pleistocene, and Holocene (Mantziou 2006). A recent study (Vamberger et al. 2014) suggests that the general genetic pattern of $M$. rivulata has been shaped 
by massive transoceanic gene flow, which is completely exceptional in the eastern Mediterranean (Lymberakis and Poulakakis 2010; Poulakakis et al. 2014). The capability of transoceanic gene flow over large distances is directly related to the great seawater tolerance of these turtles (Vamberger et al. 2014).

Distribution. - This species ranges from coastal Croatia, Serbia, Montenegro and Albania, through most of Greece (including Crete and many Aegean and Ionian islands), southeastern Macedonia and southern Bulgaria to the Marmara Sea region, Cyprus, and widely through the Mediterranean regions and river basins of western and southern Turkey to western Syria, Lebanon, northwestern Jordan, northern and central Israel, and the West Bank of Palestine.

In Jordan the species can be found throughout most of the Jordan Valley within and along the Jordan River, the Zarqa River, and in isolated habitats along the Yarmuk River, as well as in artificial temporary water bodies (e.g., dams, irrigation canals, etc.). Along those rivers the species can also be found in many man-made water bodies, such as the King Talal, Wadi Al Arab, and the Ziqlab dams (Disi et al. 2001). None of the localities with the largest populations of M. rivulata in Jordan are found within any of the Nature Reserves in Jordan.

The presence of the species is not confirmed but is possible in Bosnia and Herzegovina (Wischuf and Busack 2001; van Dijk et al. 2006; Fritz and Havaš 2007). The main factor influencing the distribution of $M$. rivulata is its adaptation to a warm Mediterranean climate (Fritz and Wischuf 1997).

Habitat and Ecology. - Mauremys rivulata occurs in a variety of natural and man-made habitats from streams to seasonal ponds, lakes, brackish coastal lagoons and drainage ditches, irrigation canals, dams and reservoirs. However, it is usually not found in fast running water (Gasith and Sidis 1983; Sidis and Gasith 1985). Individuals are usually found in the water or within close proximity of a water body; only on rare occasions are they encountered further away from water bodies. Within its southern distribution limit, $M$. rivulata is absent in water bodies in mountainous and arid regions, which seem to be major limiting factors for its distribution there (Gasith and Sidis 1983).

The Western Caspian Turtle is highly tolerant of a wide range of water conditions; it is found in acid, alkaline, and several polluted and brackish water bodies (Gasith and Sidis 1983; Sidis and Gasith 1985). Due to its great tolerance to seawater, wide sea straits, sea bays, and the open sea do not seem to constitute significant dispersal barriers to $M$. rivulata (Vamberger et al. 2014). When seasonal ponds dry up in the summer, the species responds by estivating, escaping the extreme heat experienced during this period. Sometimes individuals can also be found migrating to other water bodies during such dry seasons (Rifai and Amr 2004). In the northern areas of distribution, turtles hibernate during the winter (Arnold and Burton 1985; Engelmann 1993).

The species basks on banks or floating objects but dives quickly into the water when disturbed, disappearing within the aquatic vegetation or the muddy bottom. Juveniles and adults can usually be found in different parts of the same water body (Mantziou 2000; Rifai and Amr 2004). The smaller and more vulnerable juveniles are usually found in the shallower and muddier parts of ponds as opposed to the adults, which are often found in the deeper and clearer water. These developmental habitats provide better protection from predators for the soft-shelled juveniles.

Mauremys rivulata does not usually feed in water temperatures below $13^{\circ} \mathrm{C}$ or above $30.5^{\circ} \mathrm{C}$ (Sidis and Gasith 1985). In temperatures of $>36^{\circ} \mathrm{C}$, it is quite likely these turtles overheat; when air temperatures rise above $36^{\circ} \mathrm{C}$, they can be observed floating just below the water surface to avoid overheating, only occasionally sticking out their heads (Rifai and Amr 2004).

Several authors have discussed the diet of the Western Caspian Turtle, based on fecal analysis, dissection, and observations (Sidis and Gasith 1985; Disi 1998; Tok 1999; Wischuf and Busack 2001). Food items reported for $M$. rivulata include vegetable material, such as vascular aquatic plants, algae, saprobiontic material, and terrestrial plants and seeds (Sidis and Gasith 1985). Animal material reported in the diet has included insects and their larvae, such as coleopterans, hemipterans, chironomids, other dipterans, diplopods, arthropods and unidentified insects, as well as crustaceans, worms (Tubicifidae), aquatic snails, tadpoles, fish, and bird remains and carrion (Sidis and Gasith 1985; Disi 1998; Wischuf and Busack 2001).

It seems that the diet composition depends strongly on the available food within the habitat. Mauremys rivulata is a generalist and opportunist and can adapt to a certain degree to stressed and disturbed habitats. Stomach flushing studies on this species in Jordan yielded plant material consisting of seed, grasses, and the bearded stonewort (Chara canescens) (Rifai and Amr 2006). The same study also yielded animal material consisting mainly of anisopteran larvae and Rana bedriagae tadpoles. However, other animal remains also included adult and larval hemiptera, larval and pupal dipterans, adult hymenoptera and zygoptera, and amphibian larvae and eggs. Juvenile diet was mainly carnivorous, consisting of a wide variety of the invertebrates and vertebrates mentioned above. A dietary shift towards herbivory was observed in adults (Rifai and Amr 2006).

Male to female ratio in this species has been recorded as close to 1:1 (Wischuf and Busack 2001; Rifai and Amr 2004). In temperate zones, sexual activity was reported to be continuous from fall to spring, throughout the months 
of November to April, with a peak between January and February (Gasith and Sidis 1985). In colder regions of the species' range, mating probably takes place after the months of January and February. Nesting occurs between May and the end of July (Gasperetti et al. 1993; Mantziou 2000) with an incubation time period of about 7-11 weeks (49-77 days). Usual clutch size consists of 4-10 eggs (egg size ca. 22 x $36 \mathrm{~mm}$ ) with approximately 2-3 clutches per season, depending on the climate at the breeding site (Mantziou 2000; Rifai and Mantziou 2005; Baier et al. 2009). More research is needed on reproduction and its geographic variation in this species.

Population Status. - Due to the fact that $M$. rivulata is considered widespread and not particularly threatened, there have not been any range-wide studies on the population status for this species. According to Wischuf and Busack (2001), M. rivulata occurs in very high densities, with 19 to 217 animals per hectare in unpolluted habitats, and 500 to over 2000 animals per hectare in eutrophic wetlands.

A marginal Bulgarian population is small with about 600-1000 animals, and appears to have remained stable (Beškov 1987; Beškov and Nanev 2006). One long-term trapping study on a population inhabiting a human-impacted area along the Strymon River upstream from Kerkini Lake in northern Greece (near the Bulgarian border) showed that the population had declined dramatically from about 600 individuals in 1999 to about 150 in 2003 (Chelazzi et al. 2007).

In Cyprus, $M$. rivulata populations have declined severely due to habitat destruction. There remain only a few, very small, restricted populations (Petros Lymberakis, pers. comm.).

Populations on small Mediterranean islands, where wetlands are subject to heavy human impact and extreme weather conditions (summer drought), are very vulnerable. Extirpation of some populations has been documented in Greece due to habitat alteration or destruction and probable extinction of local populations due to organic waste pollution (Mantziou 2000). One marginal population that is at risk is the one on the small island of Gavdos, the southernmost Greek island, located $48 \mathrm{~km}$ south of Crete. The island has a very small population of about 50 animals, which is genetically distinct and morphologically differentiated from the Cretan populations (Mantziou 2006). Marginal populations and those on small islands are considered to be the ones at most risk (van Dijk et al. 2006).

Threats to Survival. - Several populations of this species have experienced severe declines during the last decades due to anthropogenic pressure throughout its range. Mauremys rivulata has dense populations in some areas, but natural wetlands are gravely endangered in the Mediterranean area, as well as in the Middle East.
Habitat loss is the main threat to survival of the species. Many aquatic habitats are either drained or canalized, because of the ever-growing demand for water, especially in island habitats in the Mediterranean region. Water demands have risen in recent decades, due to growing tourist activity and agricultural practices. Many turtle populations facing such threats are either already locally extinct or restricted to areas in which they cannot reproduce (Rifai and Mantziou 2005). Fragmentation and destruction of habitat is a growing threat for many aquatic animals, which cannot move easily to another suitable habitat. The destruction of habitat has increased in recent decades due to urban development. Habitats are often destroyed to construct roads, settlements, and hotels. The Western Caspian Turtle is a species which, although semi-aquatic, cannot move for extremely long distances in order to find new habitat. If a small pond remains near their former habitat, turtles remain there instead of searching for new habitat. Often those remaining pools have no suitable nesting sites around them; thus, in the long-term these populations could become extirpated (Mantziou 2000; Rifai and Mantziou 2005).

Another serious threat is pollution from pesticides, insecticides, fertilizers, and organic remains, which have seen an increase in use in agriculture in recent decades. All these chemicals are washed out by rain and end up in wetlands. Furthermore, many industries (e.g., oil and paper) dump their waste in streams and rivers, without having it properly treated. Although $M$. rivulata is a very tolerant species, it is not invulnerable. Probable extinctions of some local populations due to the pollution of habitats have been noted (Mantziou 2000, 2006). Additionally, recent observations made in polluted wetlands revealed that many animals exhibit morphological deformities of the shell (Mantziou 2000; Rifai and Mantziou 2005). Developmental abnormalities of this kind have previously been reported for other turtle species (Bishop et al. 1998).

The introduction and establishment of the American Slider, Trachemys scripta, is a growing threat in the long term, as this species competes for food and other resources with M. rivulata (Rifai and Amr 2004; Rifai and Mantziou 2005). This is also suggested by studies focusing on the other native Mediterranean freshwater turtle species, Mauremys leprosa and Emys orbicularis (Cadi and Joly 2004; Pérez-Santigosa et al. 2008, 2011). Trachemys scripta grows larger, has similar ecological needs, and is more aggressive than $M$. rivulata. Populations that are already stressed are more vulnerable if they also need to compete with a highly competitive and more aggressive species. The invasive $T$. scripta has already been introduced in parts of South America, South Africa, the Mediterranean region, as well as Jordan, Palestine, and Bahrain (Gasith and Sidis 1983; Gasperetti et al. 1993). Sightings of $T$. scripta in streams and ponds throughout Greece, Cyprus, 
Jordan, Syria, Palestine, and Israel seem to suggest the establishment of feral populations, which could seriously threaten the persistence of $M$. rivulata in these regions (Rifai and Mantziou 2005, pers. obs.).

Live animals and remains are sold in the pet markets in Syria and Jordan (Rifai, pers. obs.), but it is not known to what extent this is a serious threat to the survival of the species.

Conservation Measures Taken. - Mauremys rivulata is listed on Appendix II of the Convention of European Wildlife and Natural Habitats of 1979 (Bern Convention). According to the Bern Convention, species listed in Appendix II should be strictly protected.

Mauremys rivulata is listed in Annex II and IV of the European Union Council Directive 92/43/EEC. Annex II includes species of community interest whose presence requires the designation of special areas of conservation, Annex IV includes species of community interest in need of strict protection.

In Greece, M.rivulata is present in many wetlands which are included in the European Network of protected areas "Natura 2000," such as Preveli, Gavdos Island, Kournas and Agia lakes in Crete, Lake Kerkini National Park in northern Greece, and Marathonas National Park in central Greece.

The species is not yet listed on the global IUCN Red List, but an IUCN Regional evaluation for Europe and a draft global assessment by the IUCN/SSC Tortoise and Freshwater Turtle Specialist Group have both categorized the species as Least Concern. It is also listed as Least Concern in the Red Data Book of Threatened Animals of Greece.

Conservation Measures Proposed. - Most of the recent threats to the Western Caspian Turtle are primarily due to habitat destruction and degradation. To be able to protect this species in the future, such habitat destruction should be minimized. Nesting success and survival of hatchlings and, especially, adult females, are of crucial importance for the persistence of natural populations of freshwater turtles (Klemens 2000); therefore, more care needs to be taken when development threatens turtle habitats. Nesting grounds should be protected to ensure future survival of the species. Habitat alteration often causes loss of the natural wetlands complexity, which is essential for the long term well-being of the species, since M.rivulata requires a variety of habitats throughout its life and annual activity cycle (Chelazzi et al. 2007).

Wild populations (or individuals) of the introduced species Trachemys scripta should be collected and removed from Mauremys habitats. Awareness of the destructiveness of this species to local turtles needs to be raised to try to minimize future introductions of this species by pet owners.

Laws concerning industrial and agricultural waste must be enforced to minimize the heavy pollution of turtle habitats. Even though it has been shown in previous studies that these turtles can withstand some degree of pollution, evidence has also surfaced reporting morphological deformities of turtles living in heavily polluted areas (Bishop et al. 1998; pers. obs.).

Conservation-oriented studies should be carried out targeting turtles on small islands and in marginal populations. Distinct conservation and management units should be identified and protected whenever at risk, even if the species as a whole is considered non-threatened, in order avoid loss of genetic variability.

Current Research. - To the best of our knowledge, there is no active research on the biology and conservation of $M$. rivulata. The most recent research has included studies on the biology and diet of the species (Rifai and Amr 2004, 2006), population genetics and phylogeography (Mantziou et al. 2004; Mantziou 2006; Fritz et al. 2008; Vamberger et al.2014), and habitat use and behavior (Chelazzi et al.2007).

More research needs to be done on the behavior, reproductive biology, and conservation biology of M.rivulata. Population genetics studies could help identify stressed populations and distinct conservation units.

Acknowledgments. - We thank Apostolis Trichas from the Natural History Museum of Crete (NHMC) for two of the M. rivulata photos and Petros Lymberakis from NHMC for supplying information on population status and suggestions for improving the manuscript.

\section{LITERATURE CITED}

ANDERSON, S.C. 1963.Amphibians and reptiles from Iran.Proceedings of the California Academy of Sciences 31:417-498.

Arnold, E.N. AND Burton, J.A. 1985. A Field Guide to the Reptiles and Amphibians of Britain and Europe. Collins, Grafton Street, London, 272 pp.

Baier, F., Sparrow, D.J., AND WiedL, H.-J. 2009. The Amphibians and Reptiles of Cyprus. Edition Chimaira / Serpent's Tale NHBD, $364 \mathrm{pp}$.

Barth, D., Bernhard, D., Fritzsch G., and Fritz, U. 2004. The freshwater turtle genus Mauremys - a textbook example of an east-west disjunction or a taxonomic misconcept? Zoologica Scripta 33:213-221.

BEŠKov, V. 1987. Number of the stripe-necked terrapin (Mauremys caspica rivulata Valenciennes) in Bulgaria. Ekologiya 20:58-64. [In Bulgarian; English summary]

BeŠKov, V. AND Nanev, K. 2006. The Amphibians and Reptiles of Bulgaria. Pensoft Publishers, 120 pp.

Bishop, C.A., Ng, P., Pettit, K.E., Kennedy, S.W., Stegeman, J.J., Norstrom, R.J., and Brooks, R.J. 1998. Environmental contamination and developmental abnormalities in eggs and hatchlings of the common snapping turtle (Chelydra serpentina serpentina) from the Great Lakes St. Lawrence River basin (19891991). Environmental Pollution 101:143-156.

Böttger, O. 1880. Die Reptilien und Amphibien von Syrien, Palaestina und Cypern. Bericht über die Senckenbergische naturforschende Gesellschaft in Frankfurt a. Main 1880:132-220. Buhlmann, K.A., Akre, T.S.B., Iverson, J.B., Karapatakis, D., 
Mittermeier,R.A.,GeOrges,A.,Rhodin,A.G.J.,vANDiJk,P.P., AND GiBBons, J.W. 2009. A global analysis of tortoise and freshwater turtle distributions with identification of priority conservation areas. Chelonian Conservation and Biology 8(2):116-149.

BusACK, S.D. AND ERNST, C.H. 1980. Variation in Mediterranean populations of Mauremys Gray 1869. Annals of the Carnegie Museum 49(17):251-264.

CADI, A. AND JOLY, P. 2004. Impact of the introduction of the redeared slider (Trachemys scripta elegans) on survival rates of the European pond turtle (Emys orbicularis). Biodiversity and Conservation 13:2511-2518.

Chelazzi, G.,NAZiridis, T.,Benvenuti, S., Ugolini, A., ANd Crivelli, A.J. 2007. Use of river-wetland habitats in a declining population of the terrapin (Mauremys rivulata) along the Strymon River, northern Greece. Journal of Zoology 271:154-161.

Disi, A.M., Modrú, D., NeCAS, P., AND RIFAI, L. 2001. Amphibians and Reptiles of the Hashemite Kingdom of Jordan - An Atlas and Fieldguide. Frankfurt: Chimaira, 408 pp.

Eiselt, J. AND SeItZEnBerger, F. 1967. Ergebnisse zoologischer Sammelreisen in der Türkei: Testudines. Annale des Naturhisthistorischen Museums Wien 70:357-378.

Engelmann, W.E., Fritzsche, J., Gunther, R., AND OBSt, F.J. 1993. Lurche und Kriechtiere Europas. Neumann Verlag Radebeul, $440 \mathrm{pp}$.

DisI, A.M. 1998. Morphometrics, distribution and ecology of chelonians in Jordan (Reptilia: Testudines). Faunistische Abhandlungen Staatliches Museum für Tierkunde Dresden 21/ Suppl. 5:31-41.

FritZ, U. AND WischuF, T. 1997. Zur Sytematik westasiatischsüdeuropäischer Bachschildkröten(Gattung Mauremys)(Reptilia: Testudines: Bataguridae).Zoologische Abhandlungen Staatliches Mueseum für Tierkunde Dresden 49(13):223-260.

FRITZ, U. AND HAVAŠ, P. 2007. Checklist of chelonians of the world. Vertebrate Zoology 57:149-368.

Fritz, U., Ayaz, D., Buschbom, J., Kami, H.G., Mazanaeva, L.F., Aloufi,A.A.,Auer,M.,Rifai,L., Silic, T., And Hundsdorfer,A.K. 2008. Go east: phylogeographies of Mauremys caspica and $M$. rivulata - discordance of morphology, mitochondrial and nuclear genomic markers and rare hybridization. Journal of Evolutionary Biology 21:527-540.

GaSITH, A. AND SidIS, I. 1983. The distribution and nature of the habitat of the Caspian terrapin Mauremys caspica rivulata (Testudines: Emydinae) in Israel. Israel Journal of Zoology (Jerusalem) 32:91-102.

GASITH,A. ANDSIDIS,I.1985.Sexual activity in the terrapin,Mauremys caspica rivulata, in Israel, in relation to the testicular cycle and climatic factors. Journal of Herpetology 19:254-260.

GasPeretti, J.Stimson,A.F., Miller, J.D., Ross, J.P., AND GasPeretti, P.R. 1993. Turtles of Arabia. Fauna of Saudi Arabia 13:170-367.

GüNTHER, A. 1864. Report on a collection of reptiles and fishes from Palestine. Proceedings of the Zoological Society of London 1864:488-493.

IvERSON, J.B. 1992. A Revised Checklist with Distribution Maps of the Turtles of the World. Richmond, IN: Privately printed, $363 \mathrm{pp}$.

Klemens, M.W. (Ed.) 2000. Turtle Conservation. Washington, DC, Smithsonian Institution Press.

LYMBERAKIS, P. AND PoULAKAKIS, N. 2010. Three continents claiming an archipelago: the evolution of Aegean's herpetofaunal diversity. Diversity 2:233-255.

Mantziou, G. 2000. Ecology, distribution and differentiation of Mauremys caspica (Testudines: Bataguridae) in Crete. M.Sc. Thesis, University of Crete.

Mantziou, G. 2006. Phylogeography and population genetics of
Mauremys rivulata (Chelonia: Geoemydidae). Ph.D. Thesis, University of Crete.

Mantziou, G., Poulakakis, N., Lymberakis, P., Valakos, E., and Mylonas, M. 2004. The inter-and intraspecific status of Aegean Mauremys rivulata (Chelonia, Bataguridae) as inferred by mitochondrial DNAsequences. Herpetological Journal 14:35-45.

McDowell, S.B. 1964. Partition of the genus Clemmys and related problems of the taxonomy. British Journal of Herpetology 143:239-279.

Mertens, R. 1946. Über einige mediterrane Schildkröten-Rassen. Senckenbergiana 27:111-118.

Mertens, R. AND Wermuth, H. 1960. Die Amphibien und Reptilien Europas. Kramer, Frankfurt a. M., 264 pp.

Pérez-Santigosa,N.,Díaz-Paniagua, C., and Hidalgo-Vila,J. 2008. The reproductive ecology of exotic Trachemys scripta elegans in an invaded area of southern Europe. Aquatic Conservation: Marine and Freshwater Ecosystems18(7):1302-1310.

Pérez-Santigosa, N., Florencio, M., Hidalgo-Vila, J., and DíazPaniagua, C. 2011. Does the exotic invader turtle, Trachemys scripta elegans, compete for food with coexisting native turtles? Amphibia-Reptilia 32:167-175.

Poulakakis, N., Kapli, P., Lymberakis, P., Trichas, A., Vardinoyiannis, K., Sfenthourakis, S., and Mylonas, M. 2014. A review of phylogeographic analyses of animal taxa from the Aegean and surrounding regions.Journal of Zoological Systematics and Evolutionary Research. In press.

RIFAI, L. AND AMr, Z.S. 2004. Morphometrics and biology of the Stripe-necked Terrapin, Mauremys rivulata (Valenciennes, 1833), in Jordan (Reptilia: Testudines: Geoemydidae). Zoologische Abhandlungen (Dresden) 54:177-197.

RIFAI, L. AND AmR, Z.S. 2006. Diet of the Stripe-Necked Terrapin, Mauremys rivulata, in Jordan. Russian Journal of Herpetology 13(1):41-46.

Rifai, L. And Mantziou, G. 2005. L'Emyde caspienne de l'ouest, Mauremys rivulata. Manouria 29:33-36.

Sidis, I. AND GASITH, A. 1985. Food habits of the Caspian terrapin (Mauremys caspica rivulata) in unpolluted and polluted habitats in Israel. Journal of Herpetology 19:108-115.

SiebenRock, K.F. 1913. Schildkröten aus Syrien und Mesopotamien. Annale des Naturhisthistorischen Museums Wien 27:171-225.

Tок, C.V. 1999. The taxonomy and ecology of Mauremys caspica rivulata Valenciennes, 1833 (Testudinata:Bataguridae) and Testudo graeca ibera Pallas, 1811 (Testudinata:Testudinidae) on Resadiye (Datça) Peninsula. Turkish Journal of Zoology 23:17-21.

Tristram, H.B. 1884. The Survey of Western Palestine. The Fauna and Flora of Palestine, London, $455 \mathrm{pp}$.

Turtle Taxonomy Working Group [van Dijk, P.P., Iverson, J.B., Rhodin, A.G.J., Shaffer, H.B., AND Bour, R.]. 2014. Turtles of the world, 7th edition: annotated checklist of taxonomy, synonymy, distribution with maps, and conservation status. In: Rhodin, A.G.J., Pritchard, P.C.H., van Dijk, P.P., Saumure, R.A., Buhlmann, K.A., Iverson, J.B., and Mittermeier, R.A. (Eds.). Conservation Biology of Freshwater Turtles and Tortoises: A Compilation Project of the IUCN/SSC Tortoise and Freshwater Turtle Specialist Group. Chelonian Research Monographs 5(7):000.329-479.

Vamberger, M., Stuckas, H., Ayaz, D., Lymberakis, P., ŠIroký, P., AND FRITZ, U. 2014. Massive transoceanic gene flow in a freshwater turtle (Testudines: Geoemydidae: Mauremys rivulata). Zoologica Scripta, doi: 10.1111/zsc.12055.

van DiJK, P.P., Lymberakis, P., Mohammed, A., Disi, M., AJtic, R., ToK, V., Ugurtas, I., AND SEVInç, M. 2006. Mauremys rivulata. Unpublished IUCN draft assessment. 
Werner, F. 1939. Die Amphibien und Reptilien von Syrien. Abhandlungen und Berichte für Naturkunde und Vorgeschichte, Magdeburg 7:211-223.

Wettstein, O. 1928. Amphibien und Reptilien aus Palästina und Syrien. Sitzungsberichte der Akademie der Wissenschaften in Wien 10:773-784.

WetTSTEIN,O.1951.Ergebnisse derösterreichischen Iran-Expedition 1949/50. Sitzungsbericht der Österreichischen Akademie der Wissenschaften, Mathematik-Naturwissenschaften, Kl., Abt. I, 5:427-448.

WischuF,T. ANDBUSACK, S.D. 2001.Mauremys rivulata Valenciennes in Bory de Saint-Vincent et al., 1833 - Ostmediterrane Bachschildkröte. In: Fritz, U. (Ed.). Handbuch der Reptilien und Amphibien Europas. Schildkröten (Testudines) I, pp. 35-41.
ZINNER,H.1967.Herpetological collection trips to the Lebanon 1965 and 1966. Israel Journal of Zoology 16:49-58.

\section{Citation Format for this Account:}

MantZIOU, G. AND RIFAI, L. 2014. Mauremys rivulata (Valenciennes in Bory de Saint-Vincent 1833) - Western Caspian Turtle, Balkan Terrapin. In: Rhodin, A.G.J., Pritchard, P.C.H., van Dijk, P.P., Saumure, R.A., Buhlmann, K.A., Iverson, J.B., and Mittermeier, R.A. (Eds.). Conservation Biology of Freshwater Turtles and Tortoises: A Compilation Project of the IUCN/SSC Tortoise and Freshwater Turtle Specialist Group. Chelonian Research Monographs 5(7):080.1-9, doi:10.3854/crm.5.080.rivulata.v1.2014, http://www.iucn-tftsg.org/cbftt/. 